\section{Regards sur l'économie allemande}

Bulletin économique du CIRAC

$105 \mid 2012$

Varia

\title{
Culture générale
}

SPERBER H., Wirtschaft verstehen. 120 Lernmodule für Schule, Studium und Beruf

\section{(2) OpenEdition}

\section{Journals}

Édition électronique

URL : http://journals.openedition.org/rea/4431

DOI : 10.4000/rea.4431

ISBN : 978-2-8218-1420-2

ISSN : 1965-0787

Éditeur

CIRAC

Édition imprimée

Date de publication : 11 juillet 2012

ISSN : 1156-8992

Référence électronique

«Culture générale », Regards sur l'économie allemande [En ligne], 105 | juillet 2012, mis en ligne le 19 juillet 2012, consulté le 22 septembre 2020. URL : http://journals.openedition.org/rea/4431 ; DOI : https://doi.org/10.4000/rea.4431

Ce document a été généré automatiquement le 22 septembre 2020

(C) CIRAC 


\section{Culture générale}

SPERBER H., Wirtschaft verstehen. 120 Lernmodule für Schule, Studium und Beruf

\section{RÉFÉRENCE}

SPERBER H., Wirtschaft verstehen. 120 Lernmodule für Schule, Studium und Beruf, Schäffer-Poeschel Verlag, Stuttgart, 4e édition, 2012, 425 p.

1 Voilà un manuel d'économie dont on ne peut que rêver en France. Destiné aux lycéens, aux étudiants et plus généralement à tout citoyen germanophone désireux de comprendre le monde qui l'entoure, il explique dans un style compréhensible de tous, les principes et modes de fonctionnement de l'économie, illustrés et agrémentés d'encadrés, d'interviews et d'articles de presse. Il répond à toutes les questions qu'on peut se poser, de "Qu'entend-on par économique?» (aperçu de macro-économie) à «Environnement et développement» (pourquoi certains pays sont-ils pauvres et d'autres riches ? ou : comment se déterminent les prix des matières premières ?) en passant par «Money on the Move - Marchés financiers et boursiers » ou «Les grandes interactions » (globalisation, systèmes monétaires, UEM..., et jusqu'à la crise de la dette souveraine). Un remarquable ouvrage de culture générale ! (ib) 